\title{
COVID-19 LOCKDOWN: ITS EFFECT ON ENVIRONMENT
}

\author{
Madhur Mrinal ${ }^{1}$ \\ MPH Candidate, Laboratory of Disease \\ Dynamics and Molecular Epidemiology, Amity \\ Institute of Public Health
}

Abstract - Paper emphasizes the impact of lockdown on environment due to the spread of Covid-19 across the world. There are some positive changes have occurred in our environment which focuses on the health issues related with the environmental pollution and also explores such changes enhancing and sustaining our environment. It summarizes situations in our country as well as in the world- European and Asian countries for the improvement in air quality, in river water quality and in environment quality due to the spread of Covid-19 during lockdown. Mortality due to air pollution is far greater than the total number of predicted death due to corona virus, people need to understand that at present, we are fighting war with covid-19 but after this pandemic, there is an another war waiting for us and together we shall win the war from environmental pollution as well as of Covid19.

Key words: Covid-19, Lockdown, Environment, Pollution, Health)

\section{INTRODUCTION}

Several cases of an unusual pneumonia were discovered in Wuhan, a city in China during December 2019. Then China alerted WHO about these cases and other health care specialists identified it as new virus and named- novel Covid-19. Meanwhile WHO declared novel Corona virus a global health emergency as the death toll jumped to 170 people and 7,711 cases reported in that city within a month. This virus had spread over all of its provinces in China in a short span. By the end of the next week, China reported 304 deaths amid 14,380 infections. Within a few days, new cases were also confirmed from India, Philippines, Russia, Spain, Sweden, United Kingdom, Australia, Canada, Germany, Japan, Singapore, US, UAE and Vietnam (Al Jazeera, 2020). In this paper we summarize

\author{
Dr. Neha Taneja ${ }^{2}$, Dr. Rajiv Janardhanan ${ }^{3}$ \\ ${ }^{2}$ Assistant Professor, ${ }^{3}$ Director and Head, \\ Laboratory of Disease Dynamics and Molecular \\ Epidemiology, Amity Institute of Public Health
}

situations in our country as well as in the worldEuropean and Asian countries for the improvement in air quality, in river water quality and in environment quality due to the spread of Covid-19 during lockdown.

Further we have observed that there are some positive changes have occurred in our environment, focus on the health issues related with the environmental pollution and also explores such changes enhancing and sustaining our environment. Most of the countries around the globe are suffering by the Corona Virus pandemic. There is no vaccine available to control and prevent the spread of this virus. Every country follows the traditional healing rules during any unknown virus outbreak, which is only control and prevention measure left for this novel virus. Hence, most of the countries had halt international flights and sealed their borders to prevent movement of people inside and outside of the country. Many of the tourists and the people recently came back to their country put into surveillance for the checkup of Covid-19. But this was not enough as there are many cases already reported in the countries, to control this outbreak many governments announced the strategy for prevention and control of the cases by maintaining social distance, proper hygiene and lockdown.

India was also constraint to announce the largest lockdown in the world for prevention and control of Covid-19 cases. According to the present information, there are 12759 reported cases and counting, 420 death and 1514 people recovered till now. Scientists of U.S.A have projected that India could face around 100,000 and 1.3 million confirm cases of the disease caused by a new Corona virus by mid-May,2020 if it continues to spread at its current rate (Economic Times,2020a). Moreover, according to a COV-IND-19 Study Group of scholars and scientists involved in the study alarm us that "...even with the best-case scenarios, probably, you (India) 


\section{International Journal of Engineering Applied Sciences and Technology, 2020 Vol. 5, Issue 2, ISSN No. 2455-2143, Pages 563-568 \\ Published Online June 2020 in IJEAST (http://www.ijeast.com)}

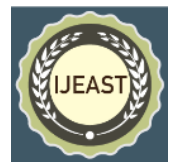

are in a very painful crisis" (ibid). At present, the $n$ Corona virus has caused 1,35,227 deaths worldwide and it may cause more damage to the humanity (Elflein,2020). People are not only fighting against Corona virus but they are also facing financial crises due to lockdown specially those people who work and get paid on daily bases and global economy is getting affected due to lockdown as many of the industries and business are shut down all over the world.

According to an estimate of WHO, three million people die each year because of the pollution; majority of the death is cause by air pollution. About $80 \%$ of the people living in an urban zone are exposing to poor air quality, which is much higher than the safe limit of air quality. Situation is more serious in developing counties and low-income countries where $98 \%$ of the cities fail to meet WHO air quality standards (Monk, 2020b). According to Lancet (2017) a study by the 40 international scientists that examined the mortality from major diseases and their cause- Air Pollution was responsible for 6.5 million deaths in 2015, water pollution cause 1.8 million death and 1 million deaths due to workplace pollution(see Sifferlin,2017).

The pollution has caused mortality is far greater than the death caused by AIDS, TB and malaria combined. In 2015, India has the highest number of 2.5 million deaths due to air pollution, followed by China, having 1.8 million deaths while United States linked to 1.5 million deaths due to pollution. The mortality rate because of pollution is much higher than the prediction of deaths caused by the novel corona virus. While humanity is facing the hard time, environment is changing positively because of an impact of covid-19 lockdown (ibid).

Methodology: The paper is based on the method of literature review and data were collected from various online articles and websites (during covid-19 pandemic) as mentioned in the references. Further, most of these articles focus present pandemic situation and the changes observed in the environment.

\section{SITUATIONAL ANALYSIS AND DISCUSSION}

\subsection{Indian situation}

The government of India has announced the largest lockdown to stop an immediate spread of $n$ Corona Virus. Social distancing is only the remedy of controlling the spread of this virus, so pollution as all the industries, markets, shops, worship places are now closed. Personal or public transport had become on halt under lockdown and it has made us to stay at home and maintain social distancing (Wright,2020).

\subsection{Improvement in Air Quality}

According to the data from the Central Pollution Control Board (CPCB), part of India's Environment Ministry, was collated by the Centre for Research on Energy and Clean Air (CREA). Main cities of India, reported lower level of microscopic particulate matter (PM 2.5) also known as PM 2.5, which is a harmful element and it may lodge deep into the lungs, and gets into other organs by going through the bloodstream. It can cause serious health risk. There is a decrease of nitrogen oxide, which is highly released by vehicles and power plants. $\mathrm{NO}_{2}$ level decreased drastically after lockdown it can be observed (seeFigure-1).

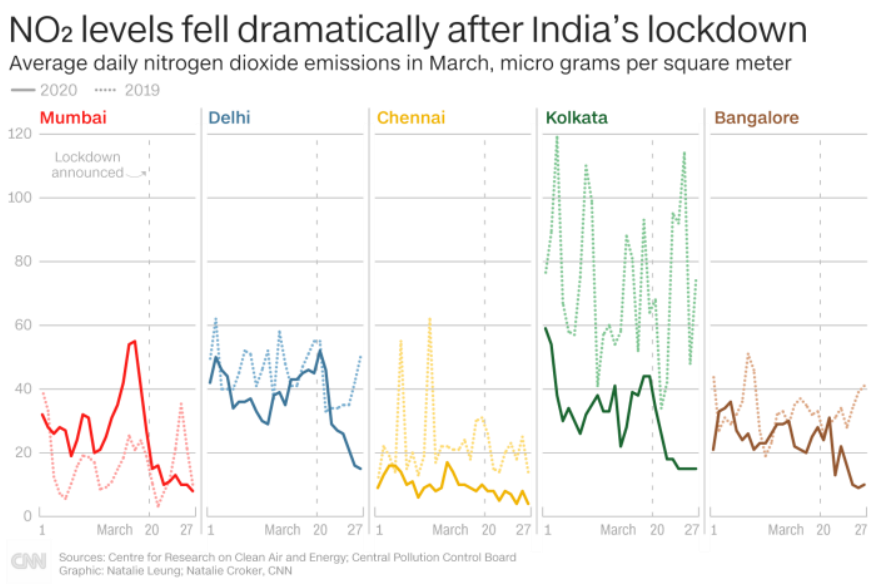

Figure-1: $\mathrm{NO}_{2}$ Level in five Indian Metro Cities (Wright,2020)

Immediate decrease in $\mathrm{NO}_{2}$ levels and PM 2.5 indicate dramatic shift in India which hold 21 rank out of world's 30 polluted countries by IQAirVisual's 2019 in World Air Quality Report. The average concentration of PM 2.5 has been reduced about $71 \%$ from 91 microgram to 20 micrograms in a week after lockdown, whereas nitrogen oxide reduced from 52 cubic meter to 15 cubic meter in a week (Wright, 2020).

The CPCB stated that Indo-Gangatic cities have shown the improvement in $\mathrm{AQI}$ value as the level of $\mathrm{NO}_{2}$ and PM 2.5 decreases. 17 cities are moving towards the satisfactory category while 7 cities are put under good AQI category. While cities like Kanpur, Vapi, Ratlam $\left(\mathrm{SO}_{2}\right.$ as prominent pollutant), Satna, Singrauli and Chandrapur have 
high AQI value and positive impact of air quality is hard to observe in these cities because of local combustion sources or emission from industrial area as there is no change in $\mathrm{PM} 2.5$ and $\mathrm{NO}_{2}$ levels(Vishnoi,2020).

\subsection{Improvement in River Water}

The Ganga and Yamuna rivers are main rivers of our country. Most of the people use their water for bathing and washing and further throwing physical garbage which leads to deteriorate quality of water in these rivers. Discharge of biological waste, from sewers and industries, are highly responsible for discharging harmful chemical substances directly into the rivers destroy the properties of rivers to heal naturally from biological waste. After the Covid-19 lockdown, most of the industries have been closed and there is a significant change in the quality of water especially around the industrial zones.

According to real time monitoring system which is based on the parameters such as dissolved Oxygen (more than $6 \mathrm{mg} /$ litre), Biochemical Oxygen Demand(BOD)(less than $2 \mathrm{mg} /$ litre), total coliform levels $(5000$ per $100 \mathrm{ml}$ ) and $\mathrm{pH}$ (range between 6.5 and 8.5) to assess the health of the rivers (PTI,2020), 27 unites out of 36 monitors which are placed at various points to check the quality of water shows that the water is suitable for bathing, wildlife and fisheries along the Ganga River. The biological waste still diluting but the Ganga River shows great improvements in self-cleansing properties (Ibid).

Yamuna water quality has also improved because of the stoppage of industrial waste mentioned by Delhi Jal Board (Ibid).Ganga Action Plan was started in 1986 to clear the river which is consider holy by the people of India. The Central Government has spent 5000 crores rupees under this plan but the impact was hardly seen until lockdown (Naqvi and Kumar,2020).

\subsection{World Scenario}

Most of the countries have used lockdown approach during mid-March this year such as France, Italy and Spain besides India, where the corona virus outbreak hit more sever in comparison to USA and Asia. There are many positive cases of corona virus in United States as well in two weeks. Hence, USA also announced lockdown in California, New York and Los Angeles as these have reported earliest positive cases of corona virus.

\subsection{Europe}

European countries such as France, Spain and Italy have also introduced lockdown in mid-March, 2020 to fight against $n$-Corona virus. There is a significant change in the reduction of pollution level in an atmosphere as it is clearly seen the drop in amount of nitrogen oxide, $\mathrm{NO}_{2}$ concentration in France(see Fig2).

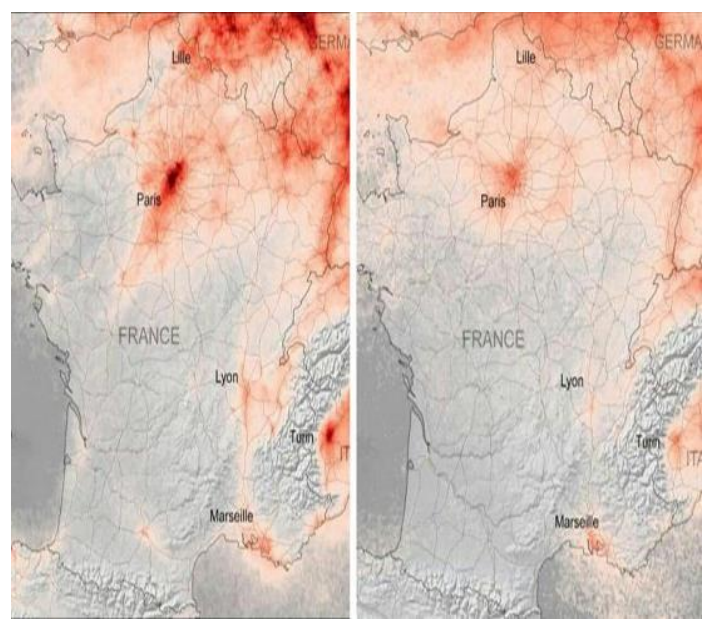

Figure-1:Before and after lockdown images of France (Gaubert,2020), taken by the Copernicus programmer's Sentinel-5P satellite,

European environmental agency had stated about the Spanish cities, Madrid and Barcelona, under strict lockdown have shown significant positive effects on its environment. The industrial businesses have been on halt and no vehicle emission as the people to stay at home and maintain social distancing. While in Italy, the average $\mathrm{NO}_{2}$ concentration level has been reduced by $50 \%$ from 2019 after the lockdown (Gaubert,2020).

\subsection{USA}

United States of America (USA) has also adopted the strict lockdown to fight against the corona virus. According to the US Environmental Protection Agency, nitrogen oxide- $\mathrm{NO}_{2}$, mainly comes from burning of fuels and from the emission of the vehicles. After the lockdown, the concentration of nitrogen oxide $\left(\mathrm{NO}_{2}\right)$ is less as compared to the last year. Reduction in concentration of pollution can be observed very clearly in California, where people are following lockdown strictly in following Satellite Images of north-east USA which show reduction of toxic gases in the atmosphere (Holcombe and O'Key,2020). 


\section{International Journal of Engineering Applied Sciences and Technology, 2020 Vol. 5, Issue 2, ISSN No. 2455-2143, Pages 563-568 \\ Published Online June 2020 in IJEAST (http://www.ijeast.com)}

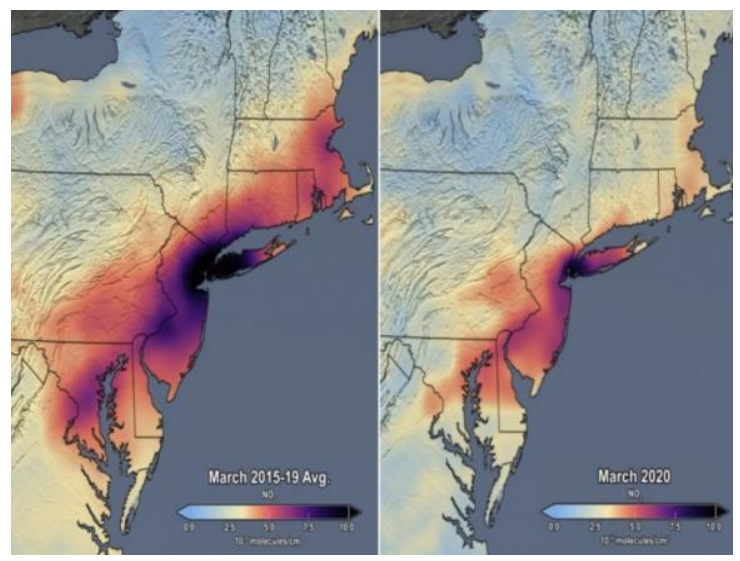

Figure-2: Image taken by NASA shows reduction in pollution (EarthSky,2020)

\subsection{Asia}

Bhattacharyya (2020) has illuminated the causes of pollution in Asia, particularly in China. It is due to large population and many industrial businesses. It is one of the most polluted nation in the world in terms of air quality. Wuhan is the epicenter of the corona virus and whole city with other cities of Hubei province went into the strict lockdown to fight against corona virus. $\mathrm{NO}_{2}$ level of China mainly comes from the vehicle's emissions and power plants but as Wuhan and its nearby zones went into the lockdown there are many factories and industrial business that are shut down and lower number of vehicles on road. These factors collectively responsible for $40 \%$ drop of $\mathrm{NO}_{2}$ concentration in China as compared to 2019 while significant drop of PM 2.5 concentrations after lockdown is also observed by the government (Monk,2020a).

Pollutant Levels in Wuhan

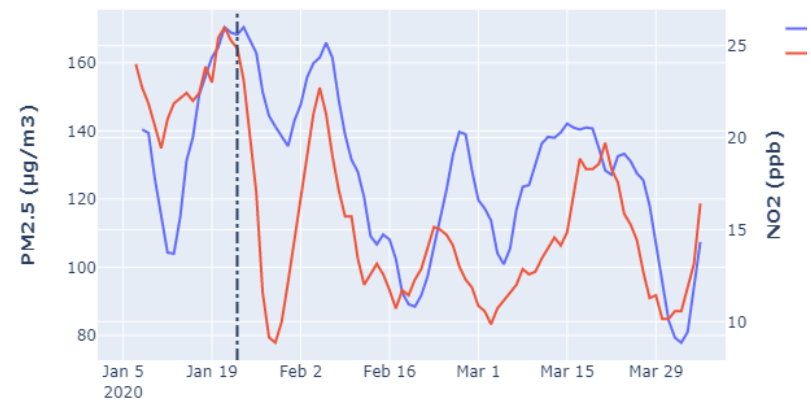

Figure-3: Pollution level of Wuhan, China (see Bhattacharyya,2020),
Satellite image from European Space Agency's Sentinel-5P satellite also claimed that during January and February 2020, there is a $40 \%$ drop in the concentration of $\mathrm{NO}_{2}$ levels over industrial areas and cities of China from 2019 (Ibid).

\section{CONCLUSION}

We feel this outbreak is a lesson to entire humanity which has shown us our actions, if we stop our actions then we can reduce the pollution level as it is observed that after lockdown days. The air pollution drastically reduced, water bodies started self-healing and ozone layer begin to repair, low concentration of PM 2.5 as well as low concentration of harmful gases such as $\mathrm{NO}_{2}$ in the atmosphere have altogether improved entire environment. The main questions we should be thinking that are these changes permanent? When lockdown will be over and life shall be back to the normal routine, industries will open again and they will try to cover up the loss due to lockdown by increasing the production, more chemical discharge from industries which will again let into the water bodies. People will use personal vehicles and avoid using public transport due to the fear of corona virus even when the situation get normal and governments will restart nuclear power plants for generating the resources, which can give boost to the economic growth of the countries.

No improvement in environment can justify the loss of life and suffering of humanity due to the outbreak of corona virus. But we should not deny the fact that numbers of death caused by the pollution are far more than the total prediction of deaths due to corona virus all over the world. Everyone was trying to minimize the pollution level but there were no changes, instead it keeps on increasing year by year due to the increase in the number nuclear power plants, population, industrial businesses and more vehicle emissions.

Lockdown also affects the global economy and many governments will ignore the pollution rules to increase the GDP of the country. There is a direct relationship of world economy and environmental pollution: as the world economy increases environmental pollution also increases and vice versa. This relationship of economy and environment was also observed at the time of 2008 recession, as there was an improvement in the environment while global economy of the world drastically went down. After the crises of 2008 recession, there was the boom in world economy rate and pollution started increasing with much higher rate than before. Another very important question on which we all 
should focus is: how to sustain these positive changes on environment without any adverse effect on people? This can only be possible with the contribution of the governments and every person of the world because it is our duty to protect and sustain the environment for ourselves as well as for future generation, if we keep continue to ignore our environment which may turn to be next health emergency concerning environmental disaster or due to the high concentration of pollution.

After the lockdown, governments should not support the industrial business so that it will not discharge chemical waste into the water bodies. It will not cause emission of harmful gases into air. Use of public transport, which runs on $\mathrm{CNG}$ and Electricity should be given more preference than using personal vehicles, more electric vehicle must be used by the people to reduce carbon emission. This will help us to reduce air pollution and the problem of traffic jams specifically in developing countries. MNCs should also consider work from home for the employees because it will help the people to cut off the time and expenditure on travelling. This will lead to better work-life balance to their employees and it indirectly contributes towards the environment. It will be win-win situation for MNCs and employees as MNCs should able to save more money because there will be no need of buying large office buildings. Governments should reduce the use of nuclear power plant and try to use the natural resources for generation of power such as solar energy, wind energy and water energy. This will be very helpful for controlling the pollution level in the environment. Establishing the power plants of these resources will cost huge amount of capital but in long-term it will be the good investment and its worth for the improvement of environment.

In the last we all feel strongly that these can reduce the concentration of pollution and improve overall condition of the environment. Government should introduce the strict rules for industries and other business which directly or indirectly contribute to the pollution. If the government induces the sense of awareness about environmental pollution and its effect on health among the people then they can feel the need of protecting the environment from pollution. Mortality due to air pollution is far greater than the total number of predicted death due to corona virus, people need to understand that at present, we are fighting war with covid-19 but after this pandemic, there is an another war waiting for us and together we shall win the war from environmental pollution as well as of Covid-19.

\section{REFERENCE}

1 Al Jazeera News(2020).Timeline: How the new s Coronavirusspread?https://www.aljazeera.com /news/2020/01/timeline-china-coronavirusspread-200126061554884.html.Accessed on 2020-04-06.

2 Bansal, S. (2020). COVID-19 Lockdown: Health of Ganga and Yamuna rivers improve. India Water Portal.https://www.indiawaterportal.org/articles /covid-19-lockdown-health-ganga-and-yamunarivers-improves.Accessed on 2020-04-10.

3 Bhattacharyya, M. (2020). An Analysis of the Impact of the Corona Virus Lockdown on our Environment, Towards Data Science.https://towardsdatascience.com/assessin g-the-impact-of-the-coronavirus-lockdown-onour-environment-through-data-

2905535da51e.Accessed on 2020-04-10.

4 EarthSky (2020). Satellite data show 30\% drop in air pollution over northeast U.S.https://earthsky.org/earth/satellite-datadrop-air-pollution-covid-march2020.Accessed on 2020-04-20.

5 Economic Times(2020a).India may have 13 lakh confirmed Coronavirus cases by mid-May: Study. The Economic Times. Health care.https:// m.economictimes.com/industry/healthcare/biote ch/healthcare/india-may-have-13-lakhconfirmed-coronavirus-cases-by-mid-maystudy/articleshow/74787214.cms.Accessed 2020-03-29.

6 Economic Times (2020b), Coronavirus outbreak: Yamuna River water quality improves after

India lock down. The Economic Times ,2020.04. 05 https://economictimes.indiatimes.com/news/ politics-and-nation/non-essential-goods-supplyby-e-commerce-to-remain-prohibited-duringlockdown-

mha/videoshow/75231234.cms, Accessed

on 2020-04-29.

7 Elflein, Jhon(2020). COVID-19 deaths worldwide as of June 17, 2020, by country. Statista

https://www.statista.com/statistics/1093256/nov 


\section{International Journal of Engineering Applied Sciences and Technology, 2020 Vol. 5, Issue 2, ISSN No. 2455-2143, Pages 563-568 \\ Published Online June 2020 in IJEAST (http://www.ijeast.com)}

el-coronavirus-2019ncov-deaths-worldwide-bycountry/Accessed on 2020-06-20.

8 Gaubert, Julie (2020).Europe breathes fresher air under lockdown as corona virus measures ease pollution. Euro News, 2020.03.30. https://www.euronews.com/2020/03/30/europebreathes-fresher-air-under-lockdown-ascoronoavirus-measures-ease-pollution.

Accessed on 2020-04-29.

9 Holcombe M. and O'Key S. (2020), Satellite images show less pollution over the US as coronavirus shuts down public places. $C N N$ Health,

2020.03.23https://edition.cnn.com/2020/03/23/h ealth/us-pollution-satellite-coronavirus-scntrnd/index.html.Accessed on 2020-04-29.

10 Lancet (2017). Commission on pollution and health (2017) , 19 October,2017, https://www.thelancet.com/commissions/polluti on-and-health.accessed on 2020/03/30

11 Monk, Paul (2020a).Coronavirus: lockdown's effect on air pollution provides rare glimpse of low-carbon future. The Conversation, Academic rigour, journalistic flair. April,15,2020.https://theconversation.com/coro navirus-lockdowns-effect-on-air-pollutionprovides-rare-glimpse-of-low-carbon-future134685. Accessed on 2020-04-29.

12 Monk, Paul ( 2020b). Here's how lockdowns have improved air quality around the world, World Economic Forum, Covid Action Platform,April,20,2020.https://www.weforum.o rg/agenda/2020/04/coronavirus-lockdowns-airpollution.Accessed on 2020-04-29.

13 Naqvi H. and Kumar S.(2020), Lockdown does what decades of schemes couldn't: Clean Ganga,Hindustan Times, New Delhihttps://www.hindustantimes.com/indianews/anxiety-more-time-to-study-for-40kstudents-stranded-in-kota/story-

LgCluBkrFEITG9qyX16IEI.htmlaccessed on 2020/04/06

14 PTI (2020), Lockdown: Health of river Ganga improves. The Economic Times, 02,April,2020https://economictimes.indiatimes. $\mathrm{com} /$ news/politics-and-nation/lockdown-healthof-river-ganga- improves/articleshow/74946264.cmsaccessed on $2020 / 04 / 05$

15 Sifferlin, A. (2017), Here's How Many People Die from Pollution Around the World. Times, October,19,2017.https://time.com/498964 1/water-air-pollution-deaths/accessed on $2020 / 03 / 30$

16 Vishnoi A. (2020), Lockdown clears up India's air. The Economic Times, 02,April, 2020. https://economictimes.indiatimes.com/news/poli tics-and-nation/lockdown-clears-up-indiasair/articleshow $/ 74942627 . \mathrm{cms}$ ?from $=$ mdraccess ed on $2020 / 04 / 30$

17 Wright R. (2020). The world's largest coronavirus lockdown is having a dramatic impact on pollution in India. CNN World Asia, 01,April,2020.https://edition.cnn.com/2020/03/3 1/asia/coronavirus-lockdown-impact-pollutionindia-intl-hnk/index.html,accessed on 2020/04/30 